\title{
Babesia vogeli in dogs from Rio Branco, South-west Amazonia, Brazil
}

\section{Babesia vogeli em cães de Rio Branco, sudoeste da Amazônia, Brasil}

\begin{abstract}
Mayara Marques Pereira Fernandes ${ }^{1}$; Marcelo Renan Serrate Rodrigues²; Jessica Damiana Marinho Valente3; Marcelli Pascoal Nogueira4; Rosany da Silva Santos Furtuoso4; Mirlane da Silva Santos ${ }^{4}$; Thállitha Samih Wischral Jayme Vieira5; Rafael Felipe da Costa Vieira6; Soraia Figueiredo de Souza7; Patrícia Fernandes Nunes da Silva Malavazi ${ }^{7 *}$
\end{abstract}

\section{Highlights}

First Record of molecular diagnosis of Babesia vogeli in South-west Amazonia.

Frequency of $2.1 \%$ of $B$. vogeli in symptomatic dogs in Rio Branco.

Co-infection of B. vogeli with Ehrlichia spp. appeared in blood smears.

\section{Abstract}

This is the first report of Babesia vogeli molecular detection in dogs from the state of Acre, northern Brazil. This study aimed to perform the molecular detection of Babesia vogeli in dogs in the municipality of Rio Branco, Acre. Blood samples were collected from 47 dogs presenting with clinical signs comparable to hemoparasitosis. These were dogs which were attended in veterinary clinics from Rio Branco municipality, Acre. Physical examinations, packed cell volume (PCV) determination, platelet number estimation, hemoparasite investigation in the blood (collected from the pinna and peripheral blood), and polymerase chain reaction (PCR) for piroplasm based on the $18 \mathrm{~S}$ rRNA gene, were performed. One dog $(1 / 47,2.1 \%$; Cl 95\%: 0.1-11.3\%) tested positive to Babesia vogeli in the polymerase chain reaction (PCR) assay for piroplasms and the resulting sequence showed $100 \%$ identity with Babesia vogeli isolates deposited in GenBank $^{\circledR}$. Co-infection with Ehrlichia spp. was also observed by direct examination (via blood smear). The

1 Veterinarian, M.e Autonomous, Rio Branco, AC, Brazil. E-mail: mpf.mayara@gmail.com

2 Veterinarian Autonomous, Curitiba, PR, Brazil. E-mail: mrserrat_rodrigues@hotmail.com

${ }^{3}$ Student of the Doctoral Course of the Postgraduate Program in Veterinary Sciences, Universidade Federal do Paraná, UFPR, Curitiba, PR, Brazil. E-mail: jessica.d.02@hotmail.com

${ }^{4}$ Veterinarian, Autonomous, Rio Branco, AC, Brazil. E-mail: marcelli.pascoal@hotmail.com, rosany.estevam@gmail. com, miirlanesantos@gmail.com

5 Veterinarian, Dra, Vector-borne Diseases Laboratory, UFPR, Curitiba, PR, Brazil. E-mail: thallitha.vieira@ufpr.br

${ }_{6}$ Prof. Dr., Vector-borne Diseases Laboratory, UFPR, Curitiba, PR, Brazil. E-mail: rvieira@ufpr.br

7 Profas Dras, Center for Biological and Natural Sciences, Universidade Federal do Acre, UFAC, Rio Branco, AC, Brazil. E-mail: soraiasouza@yahoo.com, patriciafnuness@yahoo.com.br

* Author for correspondence

Received: Apr. 19, 2021 - Approved: July 29, 2021 
clinical and hematological alterations observed in the positive animal were anorexia, dehydration, white mucous membranes, anemia and thrombocytopenia.

Key words: Diseases transmitted by ticks. Hemoparasitosis. Piroplasmosis.

\section{Resumo}

Este é o primeiro relato de detecção molecular de Babesia vogeli em cães do estado do Acre, norte do Brasil. Este estudo teve como objetivo realizar a detecção molecular de $B$. vogeli em amostras de sangue de 47 cães com sinais clínicos compatíveis com hemoparasitoses no município de Rio Branco, Acre. Tratavam-se de animais atendidos em clínicas veterinárias do município, sendo realizados exames físicos, determinação do volume globular (VG), estimativa do número de plaquetas, investigação de hemoparasitos no sangue (coletado da ponta da orelha e sangue periférico). Além disso, amostras de sangue foram submetidas a extração de DNA e reação em cadeia da polimerase (PCR) para amplificação de fragmentos do gene 18S rRNA de piroplasmas. Um cão (1/47, 2,1\%; IC 95\%: 0,1-11,3\%) apresentou resultado positivo para B. vogeli na PCR para piroplasmas e a sequência resultante mostrou $100 \%$ de identidade com os isolados de B. vogeli depositados no GenBank ${ }^{\circledast}$. Co-infecção com Ehrlichia spp. também foi observado por exame direto (esfregaço de sangue). As alterações clínicas e hematológicas observadas no animal positivo foram anorexia, desidratação, mucosas pálidas, anemia e trombocitopenia.

Palavras-chave: Doenças transmitidas por carrapatos. Hemoparasitose. Piroplasmose.

\section{Introduction}

Babesiosis is one of the most common infections caused by intraerythrocytic piroplasms in domestic animals worldwide, in addition to being an emerging zoonosis (Irwin, 2016). The transmission of Babesia vogeli infection in dogs has been observed in Brazil, considering the wide distribution of its tick vector, Rhipicephalus sanguineus sensu lato (A. P. Costa et al., 2015).

In Acre, the equatorial climate provides heat and humidity that is favorable to the survival and proliferation of ectoparasites. In Rio Branco city, the capital of the state of Acre, most dogs' infestations by ticks are associated to $R$. sanguineus species (Fernandes, Medeiros, Carvalho, Ribeiro, \& Souza, 2018).

No studies on the detection of Babesia spp. in dogs from Acre have been reported.
Thus, this study aimed to screen domiciled dogs for the presence of piroplasms in the Rio Branco municipality, Acre state, by direct examination and by polymerase chain reaction (PCR).

This study was conducted after the approval of the Ethics Committee on the Use of Animals from Universidade Federal do Acre (protocol 40/2014), and conducted according to the ethical principles of animal experimentation, adopted by the Brazilian College of Animal Experimentation.

Blood samples from forty-seven dogs of different ages (varying from 3 months to 11 years) and both sexes (27 males and 20 females) attended at private veterinary clinics of Rio Branco municipality, Acre, northern Brazil, were sampled. Dogs were eligible for the study if they presented with: (i) clinical signs (lethargy, hyperthermia, 
weight loss, epistaxis, lymph nodes' enlargement and/or splenomegaly) and/or (ii) hematological abnormalities (anemia and/ or thrombocytopenia) consistent with tickborne diseases (TBD); (iii) presence of ticks on their body surface at the time of sampling.

Dog blood samples were collected by cephalic/jugular venipuncture and stored in EDTA tubes (BD Vacutainer ${ }^{\circledR}$, Becton Dickinson, Franklin Lakes, NJ, USA) for hematological and molecular procedures. Packed cell volume (PCV) was measured by routine centrifugation and platelet count, indirectly estimated on peripheral blood smears (Thrall, Weiser, Allison, \& Campbell, 2015). Dogs were considered anemic when PCV $<0.37 \mathrm{LL}^{-1}$, and thrombocytopenia was considered when the platelet counts $<200,000 \mu \mathrm{L}^{-1}$. Additionally, blood smears of capillary origin were obtained after the introduction of a hypodermic stylet/ needle into the pinna, after antisepsis. Hemoparasites were investigated in peripheral blood smears and blood extensions of capillary origin at $1000 x$ magnification.

The DNA was extracted from $200 \mu \mathrm{L}$ blood using a commercial kit (DNeasy Blood \& Tissue $\mathrm{Kit}^{\circledR}$, Qiagen, Hilden, Germany), according to the manufacturer's instructions. Negative control purifications using ultra-pure water were performed in parallel, to monitor cross-contamination. DNA concentration and purity were evaluated by spectrophotometry (NanoDrop ${ }^{\mathrm{TM}}$, Thermo Scientific, Waltham, USA).

To ensure successful DNA extraction, PCR for glyceraldehyde-3-phosphate dehydrogenase (GAPDH) gene (Birkenheuer, Levy, \& Breitschwerdt, 2003) was performed on all samples. Thereafter, samples were screened using a conventional PCR targeting a fragment ( $\approx 500 \mathrm{bp}$ ) of the piroplasms $18 \mathrm{~S}$ rRNA gene, as previously described (J. F. Soares et al., 2011; Mongruel et al., 2017).

Amplicons (551 bp) obtained from piroplasm-positive samples were purified on an agarose gel (Wizard $^{\circledR}$ SV Gel and PCR Clean-Up System, Promega, Madison, EUA), evaluated by spectrophotometry for concentration and purity (NanodropTM 2000 Spectrophotometer, Thermo Fisher Scientific, Wilmington, MA, USA), and sequenced in both directions by the Sanger method. The assembled partial sequences of the 18S rRNA gene were subjected to BLASTn to determine their identity with sequences deposited in the GenBank $^{\circledR}$ database. The nucleotide sequence of the $B$. vogeli amplified herein was submitted to the GenBank $^{\circledR}$ database (accession number: MT386936).

Thirty-two out of 47 (68.1\%; 95\%; Cl: 53-81\%) dogs were anemic and 30/47 (63.8\%; Cl 95\%: 48-77\%) were thrombocytopenic. Thirteen out of 47 (28\%) dogs were anemic and thrombocytopenic. Additionally, 2/47 (4.3\%; Cl 95\%: 0.5-14\%) and 1/47 (2,1\%; 95\% $\mathrm{Cl}: 0,1-11,3 \%)$ dogs showed intraerythrocytic and monocytic inclusions compatible with piroplasms and Ehrlichia spp., respectively, during blood smear evaluations.

One out of 47 (2.1\%; $95 \%$; Cl:0.1-11.3\%) dogs tested positive for piroplasm by PCR. Sequencing of the 18S rRNA fragment showed $100 \%$ (551/551 bp) identity with multiple $B$. vogeli sequences deposited in GenBank $^{\circledR}$ (accession nos. MH100722, MG041384, KT323936). The dog was presenting anorexia, dehydration, white mucous membranes, anemia $\left(\mathrm{PCV}=0.25 \mathrm{LL}^{-1}\right)$, thrombocytopenia (platelet count $=15,000 \mu L^{-1}$ ), and inclusions suggestive of Ehrlichia spp. during blood smear evaluation. 


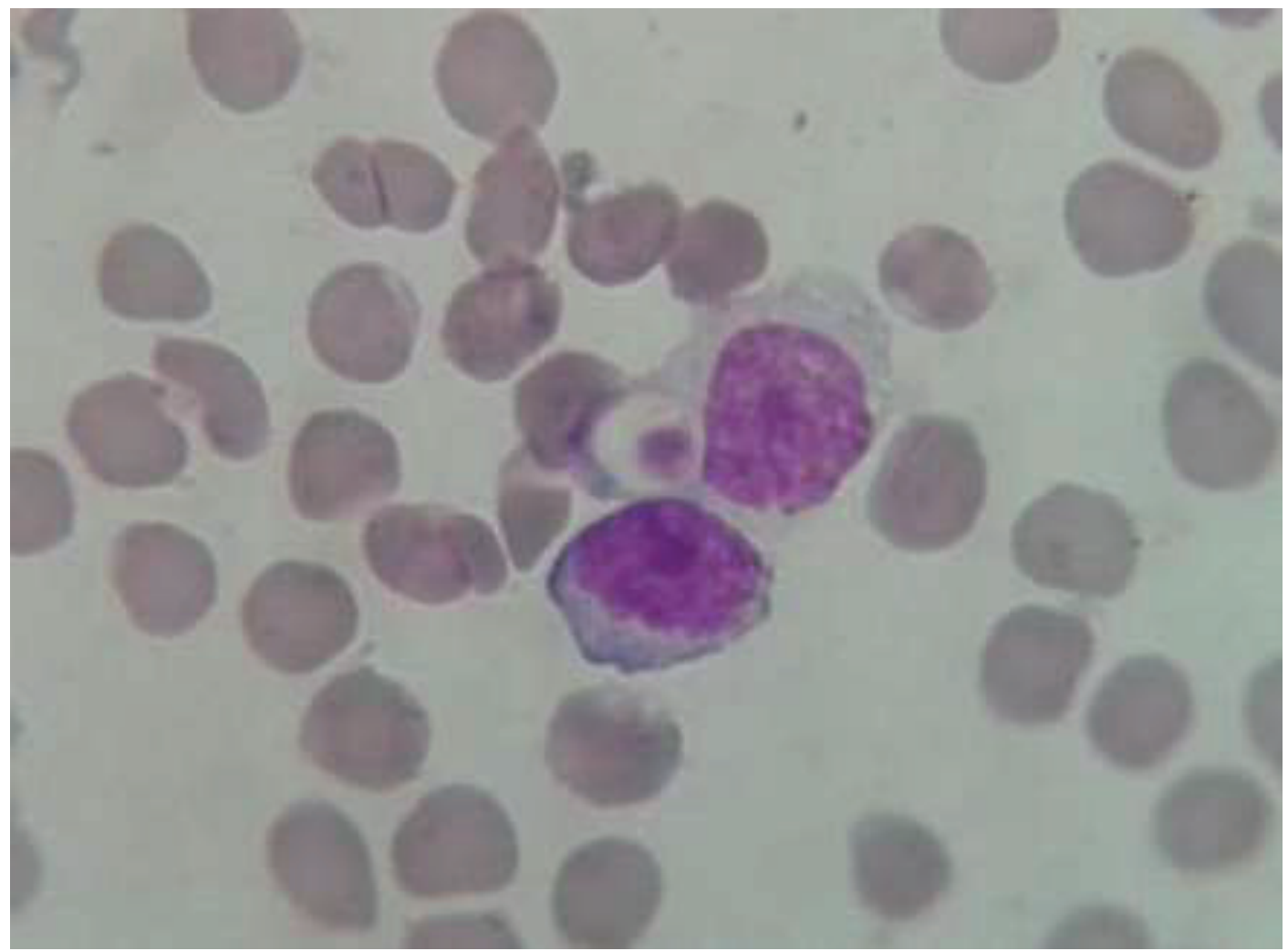

Figure 1. Ehrlichia spp. morulae in a monocyte. Blood smear, dog. 1000X magnification.

Unfortunately, ticks were not collected for taxonomic identification at the time of sampling.

Canine babesiosis cross-sectional molecular studies conducted in the Amazon biome are scarce. Galeno, Moreno and Alves (2018) observed 7.69\% (5/65) of dogs infected by $B$. vogeli in Maranhão State. In the state of Pará, scientists obtained 5\% (5/100) (Moraes et al., 2014) and 15.7\% (27/172) (Moraes et al., 2015) of $B$. vogeli positive dogs, by targeting the 18S rDNA gene. Considering the biome and the studies that investigated the parasite in dogs showing clinical signs, Rio Branco obtained the lowest infection rate (2.1\%).
The frequency of $B$. vogeli molecularly detected in symptomatic dogs from other regions in Brazil presents the following rates: $5 \%(15 / 300)$ in Goiás (H. X. Costa, 2011); 23.4\% (66/282) in Paraná (Jojima et al., 2008), and $4.8 \%(7 / 146)$ in Pernambuco (Silva et al., 2016). Jojima et al. (2008) observed the highest detection rate (23.4\%) of $B$. vogeli in a teaching hospital population.

Araujo et al. (2015) observed the presence of Babesia spp. in optical microscopy of $0.5 \%$ the evaluated animals from Pernambuco, a result lower than that found in this study. Castilho, Alves, Pereira and Coelho (2011) also found piroplasms in 3.9\% of the evaluated animals, a result similar to that obtained in this research. 
Jojima et al. (2008) observed hematological changes such as anemia and thrombocytopenia in parasitized dogs from Paraná, which were also observed in our study. Similarly, Vilela et al. (2013) verified anemia and thrombocytopenia in animals infected with $B$. vogeli in a study conducted in Rio de Janeiro. The authors observed clinical alterations such as apathy, fever, and white mucous membranes; signs that are nonspecific, as well as those found in the present study.

In a research conducted with dogs experimentally infected with $B$. vogeli Wang et al. (2018) observed fever, partial anorexia, malaise, regenerative anemia, thrombocytopenia and decreased white blood cell counts. These findings were similar to our study, corroborating its results.

Regarding $R$. sanguineus, the vector of several hemoparasites, the disease may be aggravated by $B$. vogeli co-infection with other organisms such as Ehrlichia. The interaction between Ehrlichia and B. vogeli was observed in a study conducted by H. X. Costa (2011) in Goiânia municipality. The author verified that among co-infections involving Ehrlichia, the most common was the mixed infection of $E$. canis and $B$. canis vogeli. Although most blood samples were collected from dogs with ticks, the vector species were not identified at the time of sampling. This may have compromised a possible relationship between the occurrence of the vector and the presence of hemoparasites, as described by H. S. Soares, Camargo, Gennari \& Labruna (2014).

Babesia vogeli is present in the municipality of Rio Branco and studies conducted in the Amazon biome are scarce and have a heterogeneous frequency in dog population.

\section{Acknowledgements}

Dr. Valente was sponsored by a fellowship from the Brazilian National Council of Scientific and Technological Development (CNPq) at the time of research. The CNPq also provided a fellowship of research productivity $(P Q)$ to Dr. Rafael Vieira. We would like to extend our thanks to Carolina Jardim, Gromiko Komatsu Lima, Fabiana Frota and Alexandre Farias for providing blood samples for this research.

\section{References}

Araujo, A. C., Silveira, J. A. G., Azevedo, S. S., Nieri-Bastos, F. A., Ribeiro, M. F. B., Labruna, M. B., Horta, M. C. (2015). Babesia canis vogeli infection in dogs and ticks in the semiarid region of Pernambuco, Brazil. Pesquisa Veterinária Brasileira, 35(5), 456461. doi: 10.1590/S0100-736X2015000 500012

Birkenheuer, A. J., Levy, M. G., \& Breitschwerdt, E. B. (2003). Development and evaluation of a seminested PCR for detection and differentati on of Babesia gibsoni (Asian genotype) and $B$. canis DNA in canine blood samples. Journal of Clinical Microbiology, 41(9), 4172-4177. doi: 10. 1128/jcm.41.9.4172-4177.2003

Castilho, S., Alves, J., Pereira, M. C., \& Coelho, G. (2011). Phylogenetic characterization of Babesia canis vogeli in dogs in the state of Goiás, Brazil. Revista Brasileira de Parasitologia Veterinária, 20(4), 274280. doi: 10.1590/S1984-29612011000 400004

Costa, A. P., Costa, F. B., Labruna, M. B., Silveira, I. M., Moraes, J., Fo., Soares, J. F.,... Guerra, 
R. M. S. N. C. (2015). A serological and molecular survey of Babesia vogeli, Ehrlichia canis and Rickettsia spp. among dogs in the state of Maranhão, northeastern Brazil. Revista Brasileira de Parasitologia Veterinária, 24(1), 28-35. doi: 10.1590/S1984-29612015008

Costa, H. X. (2011) Interaction of hemoparasites and hemoparasitoses in clinical cases of thrombocytopenia in dogs in the city of Goiânia. Dissertação de mestrado, Universidade Federal de Goiás, Goiânia, GO, Brasil. Recuperado de http://repositorio.bc.ufg.br/tede/handle/ tde/852

Fernandes, M. M. P., Medeiros, F. E. R., Carvalho, Y. K., Ribeiro, V. M. F., \& Souza, S. F. (2018). Ectoparasitas de cães domiciliados e errantes do município de Rio BrancoAcre. Enciclopédia Biosfera, 15(28), 442450. doi: 10.18677/EnciBio_2018B38

Galeno, L. S., Moreno, B. F. S., \& Alves, A. M. (2018). Detecção molecular de Babesia canis vogeli em cães da cidade de São Luís - MA, Brasil. Pubvet, 12(6), 1-4. doi: 10.22256/pubvet.v12n6a108.1-4

Irwin, P. (2016). Babesiosis and Cytauxzoonosis. In M. J. Day, (Ed.), Arthropod-borne infectious diseases of the dog and cat (pp.77-95). Boca Raton: CRC.

Jojima, S. F., Garcia, J. L., Vidotto, M. C., Balarin, M. R. S., Fabretti, A. K., Gasparini, M. R.,... Vidotto, O. (2008). Ocorrência e caracterização molecular de espécies de Babesia em cães de uma população hospitalar da região de Londrina, PR. Revista Brasileira de Parasitologia Veterinária, 17(1), 277-283. Retrieved from http://www.redalyc.org/articulo.oa? id $=397841469057$
Mongruel, A. C. B., Stedile, S. T. O., Sousa, M. G., Valente, J. D. M., Barbosa, I. C., Spanhol, V. C,... Vieira, R. F. C. (2017). Molecular detection of Rangelia vitalii in a dog from the Curitiba metropolitan region, Parana state, Southern Brazil. Archives of Veterinary Science, 22(4), 139-144. doi: 10.5380/avs.v22i4.56936

Moraes, P. H. G., Rufino, C. P., Baraúna, A. R. F., Reis, T., Agnol, L. T. D., Meneses, A. M. C.,... Gonçalves, E. C. (2015). Molecular characterization of Babesia vogeli in dogs from Belém, northern Brazil. Genetics and Molecular Research, 14(4), 16364-16371. doi: 10.4238/2015.December.9.4

Moraes, P. H. G., Rufino, C. P., Reis, T., Aguiar, D. C. F., Meneses, A. M. C., \& Gonçalves, E. C. (2014). Optimization of a molecular method for the diagnosis of canine babesiosis. Revista Brasileira de Parasitologia Veterinária, 23(1), 105-108. doi: 10.1590/S1984-29612014017

Silva, V. C. L., Lima, E. R., Dias, M. B. M. C. F., Fukahori, L. P., Rego, M. S. A., Pinheiro, J. W. P. Jr.,... \& Carieli, E. P. O. (2016). Parasitological and molecular detection of Babesia canis vogeli in dogs of Recife, Pernambuco and evaluation of risk factors associated. Semina: Ciências Agrárias, 37(1), 163-172. doi: 10.5433/1679-0359.2016v37n1p163

Soares, H. S., Camargo, L. M. A., Gennari, S. M., \& Labruna, M. B. (2014). Survey of canine tick-borne diseases in Lábrea, Brazilian Amazon: 'accidental' findings of Dirofilaria immitis infection. Revista Brasileira de Parasitologia Veterinária, 23(4), 473-480. doi: 10.1590/S1984-29612014093

Soares, J. F., Girotto, A., Brandão, P. E., Silva, A. S. da, França, R. T., Lopes, S. T. A., 
\& Labruna, M. B. (2011). Detection and molecular characterization of a canine piroplasm from Brazil. Veterinary Parasitology, 180(3-4), 203-208. doi: 10. 1016/j.vetpar.2011.03.024

Thrall, M. A., Weiser, G., Allison, R. W., \& Campbell, T. W. (2015). Hematologia e bioquímica clínica veterinária. Rio de Janeiro, RJ: Guanabara Koogan.

Vilela, J. A. R., Pires, M. S., Silva, C. B., Peixoto, M. P., Falqueto, A., Santos, H. A.,... Faccini, J. L. H. (2013). Alterações clínico- hematológicas da infecção por Babesia canis vogeli em cães do município de Seropédica, Rio de Janeiro, Brasil. Revista Brasileira de Medicina Veterinária, 35(1), 63-68. Retrieved from http://rbmv.org/ BJVM/article/view/576

Wang, J., Zhang, J., Kelly, P., Zheng, X., Li, M., You, J.,... Wang, C. (2018). First description of the pathogenicity of Babesia vogeli in experimentally infected dogs. Veterinary Parasitology, 253(15), 1-7. doi: 10.1016/j. vetpar.2018.02.028 
